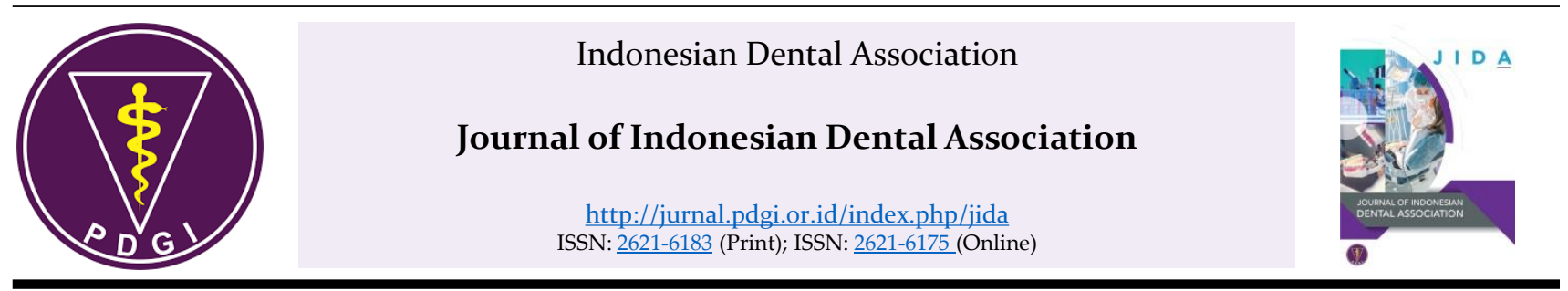

Research Article

\title{
Degree of Acidity, Salivary Flow Rate and Caries Index in Electronic Cigarette Users in Sleman Regency, Indonesia
}

\author{
Dyah Ayu Lestari1§, Regina TC. Tandelilin ${ }^{1,2}$, Friska Ani Rahman ${ }^{1}$ \\ ${ }^{1}$ Dental Hygiene Program, Faculty of Dentistry, Universitas Gadjah Mada, Indonesia \\ ${ }^{2}$ Departments of Oral Biology, Faculty of Dentistry, Universitas Gadjah Mada, Indonesia
}

Received date: November 7, 2019. Accepted date: January 29, 2020. Published date: February 20, 2020.

\section{KEYWORDS}

electronic cigarette; saliva $\mathrm{pH}$; salivary flow rate; caries index

\begin{abstract}
Introduction: The Yogyakarta Special Region ranks sixth for highest number of smokers of the 33 provinces in Indonesia. Smokers account for $31.6 \%$ of the total population. Sleman Regency ranks fourth in daily consumption of cigarettes of the five regencies or cities in Yogyakarta. The body part most exposed to direct cigarette smoke is the oral cavity. Saliva is a liquid secreted inside the oral cavity to act as a buffer. Nicotine content in conventional cigarettes is known to diminish the salivary flow rate and the acidity $(\mathrm{pH})$ of the saliva. A continual decrease in saliva $\mathrm{pH}$ over time may cause dental caries. The use of electronic cigarettes is a nicotine replacement therapy (NRT) method to help people quit smoking; they emit a lower nicotine level than conventional cigarettes. Objective: The aim of this study was to evaluate the saliva $\mathrm{pH}$, salivary flow rates, and caries index of electronic cigarette smokers. Methods: This study used a cross-sectional method to compare the saliva $\mathrm{pH}$, salivary flow rate, and caries index of 30 smokers of electronic cigarettes and 30 non-smokers as a control group. Data were analyzed using SPSS version 22.0 software and considered statistically significant at $p<0.05$. Results: The Mann-Whitney analysis showed a significant difference in the saliva $\mathrm{pH}$ between electronic cigarette smokers and non-smokers. Independent T-Test analysis showed no significant difference in the salivary flow rates of the two groups. The Mann-Whitney analysis also showed no significant difference in the caries index of the groups. Conclusion: Results indicated that there is a significant difference in the saliva $\mathrm{pH}$ of electronic cigarette smokers, while the salivary flow rates and caries indices of electronic cigarette smokers and non-smokers were similar.
\end{abstract}




\section{INTRODUCTION}

Smoking is a hard habit to break and harmful to smokers and the people around them. In Indonesia, there was no decrease in the smoking behavior of people aged 15 years and above between 2007 and 2013. Indeed, the percentage of smokers have been increased from $34.2 \%$ to $36.3 \%$ in $2013 .{ }^{1}$ The Special Region of Yogyakarta placed sixth of thirty-three provinces in Indonesia for highest number of smokers, with a prevalence of $31.6 \%$ smokers. ${ }^{2}$ Sleman Regency has the fourth highest number of smokers of the five regencies and the city in the Special Region of Yogyakarta. ${ }^{3}$

The body part most exposed to cigarette smoke is the oral cavity. Exposure to cigarette smoke may inhibit the flow of saliva, thereby diminishing the volume of saliva in the oral cavity. The findings of previous research show a strong connection between smoking, nicotine content, and decreased saliva. ${ }^{4}$ Decreased salivary flow rate triggers a decrease in bicarbonate ions promoting the occurrence of tooth and mouth abnormalities, especially caries. 5,6

The nicotine in cigarette smoke facilitates the growth and numbers of Streptococcus mutans cells on the tooth surfaces. $^{7}$ Smoking also increases the occurrence of caries by promoting the formation of $S$. mutans biofilm on the tooth surfaces. ${ }^{8} S$. mutans is a strain of bacteria that produces sticky extracellular polysaccharide, has an acidogenic tendency (a good acid-producer), and is aciduric (able to live in an acidic environment). These bacteria grow and metabolize in low $\mathrm{pH}$ environments. ${ }^{9}$ Low saliva $\mathrm{pH}$ is therefore a risk factor for dental caries. $^{10}$

The World Health Organization (WHO) has made serious efforts to reduce the tobacco epidemic. One of the chosen strategies is to replace tobacco cigarettes with electronic cigarettes. This is also in line with the findings that most electronic cigarette smokers chose to start using electronic cigarettes as an alternative to help them quit smoking. ${ }^{11}$

Electronic cigarettes, also known as an electronic nicotine delivery system (ENDS), vape, vapor, or ecigarettes, resemble tobacco cigarettes but do not burn tobacco leaves. Electronic cigarettes consist of a metal casing with a battery-powered atomizer inside to produce vapor for inhalation from a cartridge that contains humectant (such as propylene glycol and glycerol), flavorings, and nicotine. ${ }^{12}$ Electronic cigarette cartridges contain up to $24 \mathrm{mg} / \mathrm{mL}$ of nicotine extracted from tobacco. ${ }^{13}$ The aim of this study was to evaluate the level of saliva $\mathrm{pH}$, salivary flow rates, and the caries indices of electronic cigarette smokers in Sleman Regency.

\section{MATERIALS AND METHODS}

This study was conducted after obtaining an Ethical Clearance, No. 0080/KKEP/FKG-UGM/EC/2019, from the Ethics Committee of the Faculty of Dentistry, Universitas Gadjah Mada. The research used a crosssectional design to examine the differences of saliva $\mathrm{pH}$, salivary flow rate, and caries index of electronic cigarette smokers compared with non-smokers enrolled as a control group.

There were 30 test participants in this research that included only active male electronic cigarette smokers who had been smoking electronic cigarettes for a minimum of one year. The control group was recruited using a purposive sampling technic. Both groups consisted of only male participants. The profiles of the electronic cigarette smokers were obtained through a questionnaire designed by the researchers that gathered data on sex, age, and habits relating to their history of electronic smoking and the frequency of brushing teeth.

Unstimulated saliva samples were collected between 9 and 12 a.m. Participants were asked not to eat or drink anything and not to brush their teeth for sixty minutes before their saliva was collected. They were asked to sit up straight with their heads slightly bowed, facing forward, with their right hands holding the saliva container. Saliva was collected using the spitting method. The accumulated saliva was spit out into the saliva container at one-minute intervals over five minutes. Salivary flow rate was calculated by dividing the volume of the collected saliva by the time elapsed between collections. During saliva sample collection, participants were not allowed to speak, move their tongues, or chew.

The saliva $\mathrm{pH}$ was measured using a digital $\mathrm{pH}$ meter. The electrode tip of the $\mathrm{pH}$ meter detector was washed using deionized water, then dried and calibrated to the $\mathrm{pH}$ standard (7.0) before and after use. The caries index was measured using DMF-T calculated by adding the values of decay, missing, and fillings (DMF), and recording the results on an examination form. Data were analyzed using independent t-test and Mann-Whitney analysis after conducting normality and homogeneity tests. Data were considered statistically significant at $p<$ 0.05 .

\section{RESULTS}

Table 1 shows the characteristics of the test participants. The data show a significant age difference and an insignificant difference in tooth brushing frequency between the two groups. The average age of both groups was 21 years, ranging from 18 to 25 . Table 1 
shows that $70 \%$ of the electronic cigarette smokers smoke more than three times per day with an intensity of 16-20 minutes per day. Most electronic cigarette user participants smoked electronic cigarette liquid containing $3 \mathrm{mg} / \mathrm{mL}$ of nicotine.

The data normality tests used the Shapiro-Wilk test and homogeneity tests used the Levene statistic. Test results showed the saliva $\mathrm{pH}$ data did not have normal distribution and were not homogenous, with significance levels less than 0.05 . The test results showed the caries index data did not have normal distribution and homogeneity. Hypothesis tests were conducted using the Mann-Whitney test for $\mathrm{pH}$ and caries index data, and an independent t-test for salivary flow rate data. The results of the comparative analysis in Table 2 showed the significance value of salivary acidity. The caries index of the electronic cigarette smokers' group showed a significant correlation to that of the non-smokers group. The independent t-test showed no significant difference of salivary flow rate between electronic cigarette smokers and non-smokers.

Table 1. Summary of participants' characteristics and significance.

\begin{tabular}{|c|c|c|c|}
\hline \multirow{2}{*}{ Variable } & $\begin{array}{l}\text { Electronic cigarette smokers } \\
(\mathbf{n}=\mathbf{3 0})\end{array}$ & $\begin{array}{l}\text { Non-smokers } \\
\quad(\mathbf{n}=\mathbf{3 0})\end{array}$ & \multirow{2}{*}{ p-value } \\
\hline & \multicolumn{2}{|l|}{$(\%)$} & \\
\hline Age $($ Mean \pm SD $)$ & $21.73 \pm 1.46$ & $21.23 \pm 0.77$ & $0.024^{\alpha}$ \\
\hline \multicolumn{4}{|l|}{ Tooth brushing frequency } \\
\hline $1 \times$ day & $4(13.33 \%)$ & $4(13.33 \%)$ & \\
\hline $2 \times$ day & $22(73.33 \%)$ & $22(73.33 \%)$ & $1.000^{\beta}$ \\
\hline$>2 \times$ day & $4(13.33 \%)$ & $4(13.33 \%)$ & \\
\hline \multicolumn{4}{|c|}{ Frequency of electronic cigarette use } \\
\hline $1 \times$ day & $2(6.67 \%)$ & - & \\
\hline $2 \times$ day & $0(0 \%)$ & - & \\
\hline $3 \times$ day & $0(0 \%)$ & - & \\
\hline$>3 \times$ day & $28(93.33 \%)$ & - & \\
\hline \multicolumn{4}{|c|}{ Intensity of electronic cigarette use (per day) } \\
\hline 5-10 minutes & $3(10 \%)$ & - & \\
\hline $11-15$ minutes & $4(13.33 \%)$ & - & \\
\hline 16-20 minutes & $21(70 \%)$ & - & \\
\hline$>20$ minutes & $2(6.67 \%)$ & - & \\
\hline \multicolumn{4}{|c|}{ Duration of electronic cigarette use } \\
\hline$\leq 1$ year & $0(0 \%)$ & - & \\
\hline$\leq 2$ years & $20(66.67 \%)$ & - & \\
\hline$>2$ years & $10(33.33 \%)$ & - & \\
\hline \multicolumn{4}{|l|}{ Nicotine content (per ml) } \\
\hline $3 \mathrm{mg}$ & $25(83.33 \%)$ & - & \\
\hline $5 \mathrm{mg}$ & $3(10 \%)$ & - & \\
\hline $6 \mathrm{mg}$ & $2(6.67 \%)$ & - & \\
\hline
\end{tabular}

Table 2. Summary of test results, significance of degree of acidity, salivary flow rate, and caries index between groups.

\begin{tabular}{lccc}
\hline \multirow{2}{*}{ Variable } & \multicolumn{2}{c}{ Mean \pm SD } & \multirow{2}{*}{ p-value } \\
\cline { 2 - 3 } & Electronic cigarette smokers & Non-smokers & \\
\hline Degree of acidity & $6.75 \pm 0.43$ & $7.09 \pm 0.70$ & $0.028^{\alpha}$ \\
Salivary flow rate & $0.48 \pm 0.21$ & $0.50 \pm 0.22$ & $0.696^{\beta}$ \\
Caries index & $2.43 \pm 1.83$ & $2.27 \pm 2.23$ & $0.494^{\alpha}$ \\
\hline
\end{tabular}




\section{DISCUSSION}

The purpose of this study was to evaluate the differences in saliva $\mathrm{pH}$, salivary flow rate, and caries index between electronic cigarette smokers and nonsmokers in Sleman Regency. The study results showed the average age of both groups was 21 years (ranging from 18 to 25) (Table 1). The result of this study was in line with research conducted by Syauqi et al. (2017) that showed the average age of electronic cigarette smokers is 21 years. ${ }^{14}$ Table 1 shows that $70 \%$ of the electronic cigarette smoker participants reported smoking more than three times per day with an intensity of 16-20 minutes per day. As already mentioned, electronic cigarettes contain nicotine, which is the main cause of addiction. ${ }^{15}$ Electronic cigarette liquids that contain nicotine may increase the frequency of electronic cigarette use in a day. ${ }^{16}$ The above studies support the data in this study (Table 1) show that most electronic user participants used electronic cigarette liquid that contains $3 \mathrm{mg} / \mathrm{mL}$ of nicotine.

Based on Mann-Whitney test results (Table 2), it can be concluded that there is a significant saliva $\mathrm{pH}$ difference between the two groups. The saliva $\mathrm{pH}$ of electronic cigarette smokers was lower than that of nonsmokers. The result of this study is in line with previous research reporting that saliva $\mathrm{pH}$ of electronic cigarette smokers is lower than that of non-smokers. ${ }^{17}$

Nicotine has been reported to stimulate sympathetic nerves to produce neurotransmitters, including catecholamine. This may affect the alpha receptor in the blood vessels causing vasoconstriction. ${ }^{18}$ The results of this study (Table 2) indicate that the average salivary flow rate of electronic cigarette smokers is lower than that of non-smokers, even though the difference is not statistically significant. These results are in line with research conducted by Fitriasani et al. (2017) ${ }^{4}$ showing that higher nicotine content in conventional cigarettes may cause a lower volume of saliva. Vasoconstriction may decrease salivary gland function and reduce saliva secretion, which may lead to a decrease of bicarbonate ions in the saliva. A decrease in bicarbonate ion decreases the saliva $\mathrm{pH}^{18}$ The hot smoke produced by cigarettes may disperse to all parts of the oral cavity and suppress the saliva reflex, leading to a change in salivary flow rate. ${ }^{19}$ Furthermore, nicotine may also cause morphological and functional abnormalities of the salivary glands that reduce the salivary flow rate. ${ }^{20}$

The higher nicotine content in the liquid aerosol of electronic cigarettes will precipitate on the oral mucosa that have a slower absorption rate; therefore more nicotine will be absorbed into the body through the ingestion process. ${ }^{21}$ The lower content of nicotine in electronic cigarettes and the lower amount of absorbed nicotine may cause an insignificant difference in the salivary flow rate between the two groups, in contrast with tests comparing electronic cigarette smokers with conventional tobacco smokers.

Lower saliva $\mathrm{pH}$ is known to increase the growth of pathogens that cause periodontal diseases. ${ }^{22}$ An acidic environment is beneficial for the microorganisms that cause periodontitis, such as Porphyromonas gingivalis that growth in a $\mathrm{pH}$ of 6.5-7.0, Prevotella intermedia that growth in a pH of 5.0-7.0, and Fusobacterium nucleatum that growth in a $\mathrm{pH}$ of $5.5-7.0 .^{23}$

Based on the Mann-Whitney analysis results (Table 2 ), it can be concluded that there is no significant difference in the caries index between electronic cigarette smokers and non-smokers. This result is in agreement with previous research reporting no significant differences in the caries index of a control group, conventional cigarette smokers, and electronic cigarette smokers. The main cause in the etiopathogenesis of dental caries is biofilm. ${ }^{24}$ Biofilm that accumulates in the hard tissues in the oral cavity forms dental plaque which then develops and eventually causes caries. ${ }^{25}$

Electron microscopy scanning has shown that $S$. mutans exposed to high concentrations of nicotine had thicker biofilm. Thick biofilms increase the development of caries on the tooth surface. ${ }^{26}$ Caries is a multifactorial disease that is influenced by microorganisms, substrate, host (teeth), and time. Dental caries can only occur if the four forming factors are present. ${ }^{27}$ Furthermore, the caries index can be affected by knowledge, tooth brushing habits, cariogenic food consumption, parents' roles, and the utilization of dental health facilities. ${ }^{28}$

\section{CONCLUSION}

The saliva $\mathrm{pH}$ of electronic cigarette smokers is lower than that of non-smokers. The salivary flow rate and the caries index of electronic cigarette smokers are similar to those of non-smokers.

\section{CONFLICTS OF INTEREST}

The author declares there are no conflicts of interest regarding this study.

\section{REFERENCES}

1. Indonesia. Department of Health Republic of Indonesia. Basic Health Research 2013. Jakarta: Ministry of Health of The Republic of Indonesia; 2013. p. 5.

2. Indonesia. Department of Health Republic of 
Indonesia. Basic Health Research 2010. Jakarta: Ministry of Health of The Republic of Indonesia; 2010. p. 28.

3. Indonesia. Department of Health Republic of Indonesia. Yogyakarta Health Profile 2017. Jakarta: Ministry of Health of The Republic of Indonesia; 2018. p. 28.

4. Fitriasani I, Lestari PE, Wati LR. Hubungan Merokok Bernikotin terhadap Penurunan Volume Saliva pada Perokok di Kabupaten Tulungagung, eJurnal Pustaka Kesehatan. e-Journal Pustaka Kesehatan. 2017;5(3):437-440.

5. Rad M, Kakoie S, Brojeni FN, Pourdamghan N. Effect of long-term smoking on whole-mouth salivary flow rate and oral health. J Dent Res Dent Clin Dent Prospects. 2010;4(4):110-114.

6. Kanwar A, Sah K, Grover N, Chandra S, Singh RR. Long-term effect of tobacco on resting whole mouth salivary flow rate and $\mathrm{pH}$ : an institutional based comparative study. Eur J Gen Dent. 2013;2:296-299.

7. Liu S, Wu T, Zhou X, Zhang B, Huo S, Yang Y, et al. Nicotine is a risk factor for dental caries: an in vivo study. J Dent Sci. 2018;13:30-36.

8. Huang R, Li M, Gregory RL. Effect of nicotine on growth and metabolism of Streptococcus mutans. Eur J Oral Sci. 2012;120:319-325.

9. Kidd E, Fejerskov O. Essentials of dental caries. Oxford: Oxford University Press; 2016. pp. 7.

10. Bebe ZA, Susanto HS, Martini. Faktor Risiko Kejadian Karies Gigi pada Orang Dewasa Usia 2039 Tahun di Kelurahan Dadapsari, Kecamatan Semarang Utara, Kota Semarang, Jurnal Kesehatan Masyarakat (eJournal). 2018;6(1):365-374.

11. Damayanti A. Penggunaan Rokok Elektronik di Komunitas Vaporizer Surabaya, Jurnal Berkala Epidemiologi. 2016;4(2):250-261.

12. Etter J-F, Bullen C. Electronic cigarette: users profile, utilization, satisfaction and perceived effiacy. Addiction. 2011;106(11):2017-2028.

13. Kaisar MA, Prasad S, Liles T, Cucullo L. A decade of e-cigarettes: limited research \& unresolved safety concerns. Toxicol. 2016;365:67-75.

14. Syauqi A, Fitri AD. Pengaruh Merokok terhadap pH Saliva dan aktivitas Enzim Ptialin pada Mahasiswa Fakultas Kedokteran dan Ilmu Kesehatan Universitas Jambi. Jambi Medical Journal. 2017;5(1):29-40.

15. Mishra A, Chaturvedi P, Datta S, Sinukumar S, Joshi P, Garg A. Harmful effects of nicotine. Indian J Med Paediatr Oncol. 2015;36(1):24-32.

16. Kinnunen JM, Ollila H, Minkkinen J, Lindfors PL,
Timberlake DS, Rimpela AH. Nicotine matters in predicting subsequent smoking after e cigarette experimentation: a longitudinal study among Finnish adolescents. Drug Alcohol Depend. 2019;201:182187.

17. Qalbi MZ, Irrahmah M, Asterina. Perbedaan derajat Keasaman $(\mathrm{pH})$ Saliva antara Perokok dan Bukan Perokok pada Siswa SMA PGRI 1 Padang. Jurnal Kesehatan Andalas. 2018;7 (3):358-363.

18. Sharma S, Mishra SK, Mittal N. Influence of tobacco dependence on caries development in young male adults: a cross-sectional study. J Conserv Dent. 2018;21(6):597-601.

19. Khan GJ, Javed M, Ishaq M. Effect of smoking on salivary flow. Gomal J Med Sci. 2010;8(2):221-224.

20. Almeida PDV, Gregio AMT, Machado MAN, Lima AAS, Azedo LR. Saliva composition and function: a comprehensive review. J Contemp Dent Pract. 2008;9(3):1-11.

21. Farsalinos KE, Spryou A, Tsimopoulou K, Stefopoulos C, Romagna G, Voudris V.. Nicotine absorption from electronic cigarette use: comparison between first and new-generation devices. Sci Rep. 2014;4(4133):1-7.

22. Seethalakshmi C, Reddy RCJ, Asifa N, Prabhu S. Correlation of salivary $\mathrm{pH}$, incidence of dental caries and periodontal status in diabetes mellitus patients: a cross-sectional study. J Clin Diagn Res. 2016;10(3):ZC12-ZC14.

23. Ghazali AF, Ismail AF, Daud A. Caries experience among cigarette and e-cigarette users: a 6-month prospective study. J Pharm Sci Res. 2019;11(7):2566-2569.

24. Tandelilin RTC, Saini R. Dental plaque: a biofilm. Yogyakarta: PT Kanisius; 2018. pp. 1.

25. Tandelilin RTC, Widita E, Agustina D, Saini R. The effect of oral probiotic consumption on the caries risk factors among high risk caries population. J Int Oral Health. 2018;10(3):132-137.

26. Huang R, Li M, Gregory RL. Effect of nicotine on growth and metabolism of Streptococcus mutans. Eur J Oral Sci. 2012;120:319-325.

27. Kidd EAM, Joyston-Bechal S. 2013. Dasar-Dasar Karies Penyakit dan Penanggulangannya. Jakarta: EGC; 2013. pp. 2, 16-17, 73-74.

28. Alini. Faktor-Faktor yang berhubungan dengan Kejadian Karies Gigi pada Murid SDN.005 Kepenuhan Wilayah Kerja Puskesmas Kepenuhan. Jurnal Basicedu. 2018;2(1):19-2. 